\title{
Forest structure and tree species composition of the Grand Etang Forest on Grenada, West Indies, pre-Hurricane Ivan
}

\author{
MARY E. GLENN ${ }^{1,2}$ AND KEITH J. BENSEN ${ }^{2}$ \\ ${ }^{1}$ Department of Anthropology, Humboldt State University, Arcata, CA 95521 USA \\ ${ }^{2}$ Windward Islands Research and Education Foundation, Grenada, West Indies. Contact information for corresponding \\ author: Tel: (707) 826-3126 Fax: (707) 826-4418 Email: mary.glenn@humboldt.edu
}

\begin{abstract}
The last comprehensive native forest structure survey made in the Grand Etang National Park and Forest Reserve of Grenada was in the 1940s, before Hurricane Janet hit the island in 1955. The data from this study were collected in the mid-1990s, previous to the devastation of Hurricane Ivan in 2004, the first hurricane to strike Grenada since 1955. A total of 584 trees representing 41 species were identified in twenty $2 \mathrm{~m} \times 50 \mathrm{~m}$ plots. Mean tree height, basal area per hectare, tree density per hectare, and species richness were determined for the park and forest reserve. Licania ternatensis was the dominant tree in terms of density per hectare $(18 \%)$, while Dacryodes excelsa was dominant in terms of basal area per hectare $\left(30.3 \mathrm{~m}^{2}\right)$. Trichillia septentrionalis had the largest mean height $(23.6 \mathrm{~m})$ even though the tallest tree in the sample was a Dacryodes excelsa $(51.9 \mathrm{~m})$. The composition of the Grand Etang forest in the 1990s consisted of a mosaic of stands of different size classes and species composition, most likely indicating varying damage and recovery from Hurricane Janet. Additional surveys are recommended to reassess Grenada's Grand Etang native rainforest structure in order to determine which tree species are recovering and at what rate after the devastation of Hurricane Ivan. These results could then be compared to the significant body of work done on ecologically similar hurricane affected wet/rain and lower montane wet/rain forests found on Puerto Rico.
\end{abstract}

KEYWORDS.-Rainforest, Caribbean, Licania ternatensis, Dacryodes excelsa, Trichillia septentrionalis

\section{INTRODUCTION}

In the Grand Etang National Park and Forest Reserve, only one comprehensive forest structure survey was made previous to this study (Beard 1944, 1949). In 1955, Hurricane Janet passed directly over Grenada and caused damage to the Grand Etang forest, altering much of its previous structure (Caribbean Conservation Association 1991). Our forest structure and composition surveys were conducted in the mid-1990s as part of a larger study concentrating on the natural history and ecology of the introduced mona monkey (Cercopithecus mona) (e.g., Glenn 1996, 1997, 1998, Horsburgh et al. 2002). In 2004, Hurricane Ivan devastated most of the Grand Etang forest. Our surveys were completed after Hurricane Janet and before Hurricane Ivan, and provide a picture in time of a Lesser Antillean rainforest almost a half century after a major disturbance and less than ten years before an even larger disturbance. In order to better understand the forest's current condition and species survivorship and succession rates, future surveys describing Grand Etang's forest structure and species composition should be conducted and then compared to the material presented here.

\section{MATERIALS AND METHODS}

\section{Study Site}

Grenada, which is located $150 \mathrm{~km}$ north of South America, is the southernmost island in the Lesser Antilles' archipelago (Figure 1). The island is $33.5 \mathrm{~km}$ long and $19 \mathrm{~km}$ wide, and has a total area of approximately $312 \mathrm{~km}^{2}$. The topography of Grenada consists of a series of highly eroded volcanic peaks (the highest being Mt. St. Catherine at $850 \mathrm{~m}$ ) that run along the center of the island. The lower elevations contain cultivated lands consisting mainly of tree crops (primarily nutmeg, cocoa, and 


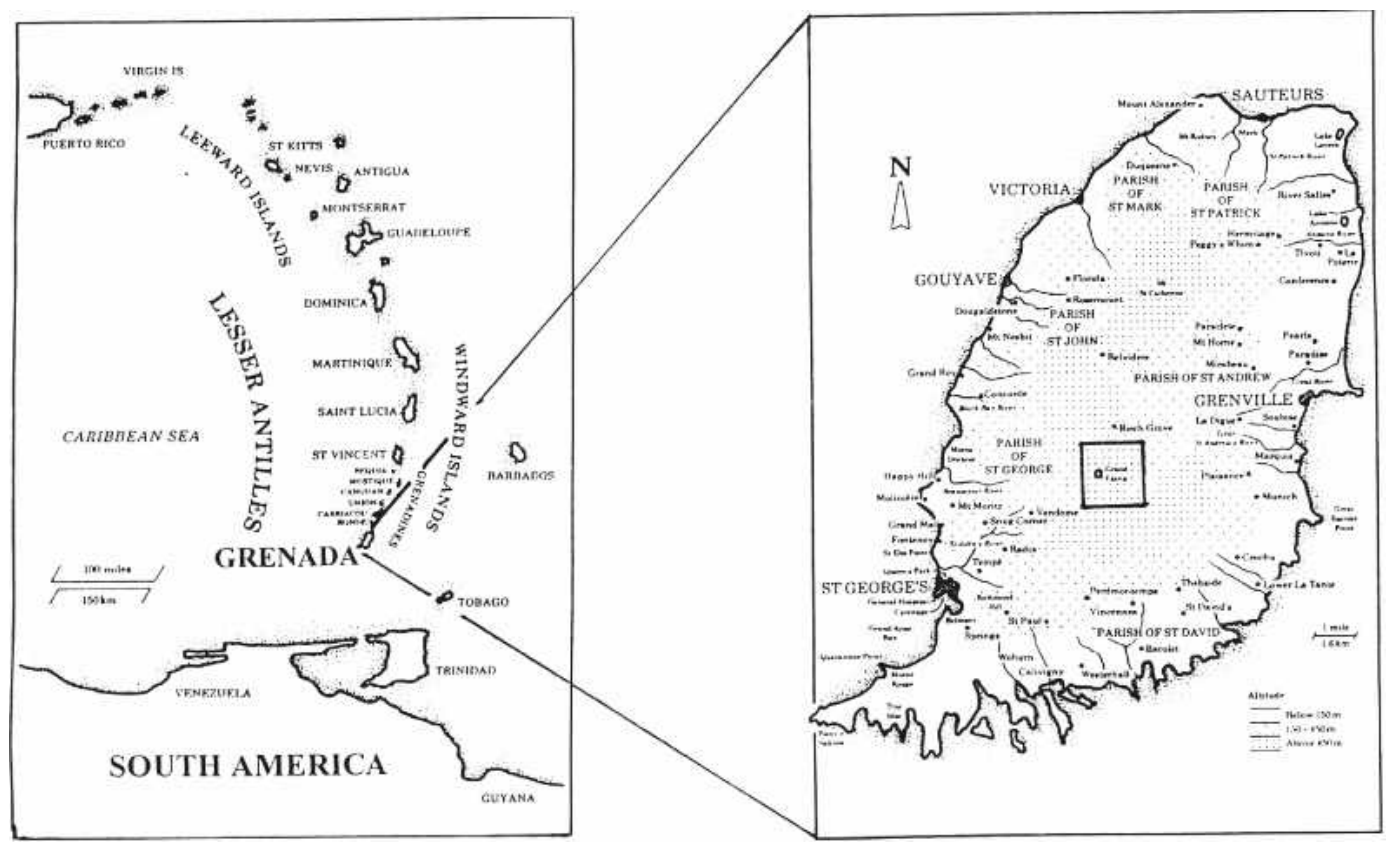

FIG. 1. Location of the study site on the island of Grenada.

bananas), dry scrub woodlands, and mangrove swamps that occur along shallow bays and inlets. Most towns and villages are located at lower elevations and along the coast. Upper elevations receive more rain and have a thicker forest cover, with rain forest generally occupying elevations above $350 \mathrm{~m}$ (Caribbean Conservation Association 1991). Ridge tops and peaks are covered in short, thick forest (termed "elfin woodland") that does not exceed $5 \mathrm{~m}$ in height (Beard 1949).

The Grand Etang National Park and Forest Reserve on Grenada $\left(12^{\circ} 6^{\prime} \mathrm{N}, 61^{\circ} 42^{\prime} \mathrm{S}\right)$ occupies approximately 1,540 ha of mountainous, tropical rain forest (Figure 1). The forest reserve was originally set aside in 1902 in order to protect vital watersheds for lower elevation croplands. No tree harvest has been conducted within the reserve over the past century except within small areas that were replanted with exotic hardwoods after the 1955 hurricane damaged parts of the forest (Caribbean Conservation Association 1991). The terrain is characterized by volcanic craters (one of which contains the Grand Etang Lake), steep slopes, narrow ridges, and numerous small perennial streams on the bottom of deep ravines and valleys. The elevation within the Grand Etang forest ranges between 340 and $710 \mathrm{~m}$.

The Grand Etang forest receives an average of 4,060 mm of rain per year (Grenada Government and Organization of American States 1988). A total of 3,422 $\mathrm{mm}$ of rain fell in the one continuous year (1993) during which climactic data were collected at the Grand Etang field station. Mean monthly rainfall at the field station was $252.8 \mathrm{~mm}(\mathrm{SD}=143)$, and temperatures averaged $21.3^{\circ} \mathrm{C}(\mathrm{SD}=1.3)$ over 28 months between September 1992 and April 1995. Trade winds blow across the Grand Etang forest year-round.

\section{Forest Structure Surveys}

Forest structure surveys were conducted between 28 October 1994 and 5 April 1995. Twenty, $2 \mathrm{~m} \times 50 \mathrm{~m}$ plots were installed throughout the study area. Plots were placed at random perpendicular distances (0-500m, generated from a random numbers table) from monkey survey trails every $500 \mathrm{~m}$ with the direction determined by the flip of a coin. Several small plots were used 
instead of a few large plots because preliminary surveys indicated that the Grand Etang forest was highly variable in structure and species composition over small areas and had low overall species richness.

Each tree within each plot was identified to species and measured with a diameterat-breast-height $(\mathrm{DBH})$ tape. Only trees with a DBH of $3 \mathrm{~cm}$ or greater were included in this analysis. Tree density was calculated as the number of trees per species per hectare or the number of trees per forest type per hectare. The basal area of each tree was calculated from $\mathrm{DBH}$ measurements using the following formula: $(\mathrm{DBH} / 2)^{2}(\pi)$. Basal area per species per hectare and basal area per forest type per hectare were then derived from these calculations. Each tree within each plot was measured for height with a clinometer. Canopy cover for each plot was visually estimated with a spherical densiometer. Final tree identification and taxonomic classification were based on Howard's Flora of the Lesser Antilles, Leeward and Windward Islands (1989). Mean tree height, basal area per hectare, tree density per hectare and species richness between primary and secondary forest types were compared using t-tests (one-tailed) with a $95 \%$ confidence level.

\section{RESULTS}

A total of 584 trees were measured within the 20 plots. A summary of tree species composition and structure is provided in Table 1. Forty-one tree species were represented. Six of the 41 species were not identified. Unidentified trees, however, made up only $2.3 \%(n=12)$ of the total number of trees within the plots. Licania ternatensis was the dominant tree in terms of density per hectare $(18 \%, \mathrm{n}=525)$, whereas Dacryodes excelsa was dominant in terms of basal area per hectare $\left(30.3 \mathrm{~m}^{2}\right)$. Trichillia septentrionalis had the largest mean height $(23.6 \mathrm{~m})$ even though the tallest tree in the sample was a Dacryodes excelsa $(51.9 \mathrm{~m})$.

Three divisions of rain forest types were made based on tree structure and species composition (Table 2). Two of these types, primary and secondary, were identified by successional stages; the third forest type, palm brake (Beard 1949), was a specific vegetation category. Primary forest was characterized by emergent species such as Dacryodes excelsa and Sloanea spp., while secondary forest was characterized by species of woody shrubs such as Psychotria berteriana, Miconia spp., and Citharexylum spinosum. Palm brake consisted of a minimum of $33 \%$ and up to $60 \%$ of palm trees (Prestoea montana and Euterpe dominicana).

Primary forest was the prevalent forest type and occurred in 11 of the 20 plots. Secondary forest and palm brake occurred in six and three of the 20 plots, respectively. Primary forest had significantly lower species richness than secondary forest $(t=4.79$, $\mathrm{n}=17, \mathrm{p}<0.0001)$. In addition, primary forest had a significantly lower tree density per hectare $(\mathrm{t}=4.79, \mathrm{n}=17, \mathrm{p}<0.0002)$ but a significantly higher mean tree height $(\mathrm{t}=$ $4.76, \mathrm{n}=533, \mathrm{p}<0.0005)$ than did secondary forest. No differences were found between primary and secondary forest for basal area per hectare $(\mathrm{t}=0.97, \mathrm{n}=17, \mathrm{~ns})$. Palm brake had the lowest mean tree density per hectare, basal area per hectare, tree height, and species diversity of all three forest types. No differences were found for percentage of canopy cover among forest types. Mean canopy coverage for all forest types combined was $97.8 \%(\mathrm{SD}=5.6, \mathrm{n}=$ 20 ) with a range between $75 \%$ and $100 \%$.

\section{DISCUSSION}

The forest of Grenada's Grand Etang National Park and Forest Reserve during the 1990s was similar to the subtropical wet/ rain forest and lower montane wet/rain forest types of Puerto Rico. These Puerto Rican forests receive similar amounts of rainfall, are found at similar elevations and have been disturbed periodically by hurricanes. They also have the same dominant species (in terms of height and basal area), Dacroydes excelsa and Slonea spp., as well as the same abundant palm species (in terms of density and basal area), Prestoea Montana, as the Grand Etang forest (Weaver 1989, Brandeis et al. 2007). The most 
TABLE 1. Structural summary of trees in the Grand Etang Forest.

\begin{tabular}{|c|c|c|c|c|c|c|}
\hline \multirow[b]{2}{*}{ Family and species } & \multirow[b]{2}{*}{$\mathrm{N}$} & \multicolumn{3}{|c|}{ Height (m) } & \multirow[b]{2}{*}{ Dens. $^{*}$} & \multirow[b]{2}{*}{ BAt } \\
\hline & & Mean & SD & Range & & \\
\hline \multicolumn{7}{|l|}{ Annonaceae } \\
\hline Guatteria caribaea Urban & 10 & 11.4 & 5.0 & $5.5-20.7$ & 50 & 1.55 \\
\hline \multicolumn{7}{|l|}{ Aquifoliaceae } \\
\hline Ilex dioica (M. Vahl.) Griseb. & 15 & 14.4 & 5.3 & $6.8-24.3$ & 75 & 1.23 \\
\hline Ilex sideroxyloides (Sw.) Griseb. & 19 & 11.9 & 4.8 & $4.9-18.2$ & 95 & 2.13 \\
\hline \multicolumn{7}{|l|}{ Burseraceae } \\
\hline Dacryodes excelsa Vahl. & 73 & 15.7 & 10.3 & $4.7-51.9$ & 365 & 30.31 \\
\hline \multicolumn{7}{|l|}{ Celastraceae } \\
\hline Cassine xylocarpa Vent. & 31 & 13.6 & 5.3 & $3.0-25.5$ & 155 & 3.24 \\
\hline \multicolumn{7}{|l|}{ Chrysobalanaceae } \\
\hline Licania ternatensis Hooker f. ex. Duss & 10 & 11.7 & 6.6 & $2.5-35.0$ & 525 & 8.03 \\
\hline \multicolumn{7}{|l|}{ Cyatheaceae } \\
\hline Cyathea tenera J. (Smith ex. Hook) T. Moore & 1 & 11.9 & - & - & 5 & 0.06 \\
\hline \multicolumn{7}{|l|}{ Elaeocarpaceae } \\
\hline Slonea massoni Sw. & 18 & 12.9 & 9.0 & $3.6-36.6$ & 90 & 7.00 \\
\hline Slonea caribaea Krug \& Durban ex. Duss & 47 & 11.4 & 7.5 & $2.0-37.4$ & 235 & 9.55 \\
\hline \multicolumn{7}{|l|}{ Lauraceae } \\
\hline Ocotea leucoxylon (Sw.) De Laness & 5 & 9.3 & 4.0 & $3.5-13.5$ & 25 & 0.11 \\
\hline \multicolumn{7}{|l|}{ Malvaceae } \\
\hline Hibiscus elatus Sw. & 10 & 12.4 & 3.7 & $6.0-17.6$ & 50 & 1.49 \\
\hline \multicolumn{7}{|l|}{ Melastomataceae } \\
\hline Miconia andersonii Fawcett \& Rendle & 4 & 7.9 & 1.7 & $5.5-9.5$ & 20 & 0.05 \\
\hline Miconia praesina (Sw.) DC. & 6 & 7.0 & 1.8 & $4.6-9.5$ & 30 & 0.06 \\
\hline Miconia trichotoma (Desr.) DC. & 5 & 5.6 & 1.3 & $4.0-7.0$ & 25 & 0.10 \\
\hline \multicolumn{7}{|l|}{ Meliaceae } \\
\hline Guarea macrophylla Vahl. & 8 & 10.9 & 7.9 & $3.5-23.5$ & 40 & 0.93 \\
\hline Trichillia septentrionalis C. DC. & 4 & 23.6 & 12.7 & $6.9-35.0$ & 20 & 1.83 \\
\hline \multicolumn{7}{|l|}{ Mimosoideae } \\
\hline Pithecellobium jupunba (Wild.) Urban & 3 & 11.4 & 1.7 & $9.7-13.2$ & 15 & 0.26 \\
\hline Zygia latifolia (L.) Fawcett \& Rendle & 8 & 6.8 & 2.7 & $4.0-11.2$ & 40 & 0.09 \\
\hline \multicolumn{7}{|l|}{ Moraceae } \\
\hline Ficus americana Aublet & 3 & 16.6 & 9.0 & $10.1-26.8$ & 15 & 0.76 \\
\hline \multicolumn{7}{|l|}{ Myrsinaceae } \\
\hline Myrsine coriacea (Sw.) R. Br. Roemer \& Schultes & 1 & 15.0 & - & - & 5 & 0.03 \\
\hline Myrtaceae & & & & & & \\
\hline Pimenta racemosa (Miller) T. Moore & 12 & 8.4 & 3.6 & $5.0-16.8$ & 60 & 0.18 \\
\hline Szygium jambos (L.) Alston & 2 & 5.6 & 2.2 & $4.0-7.1$ & 10 & 0.13 \\
\hline Palmae & & & & & & \\
\hline Euterpe dominicana Bailey & 7 & 14.7 & 6.8 & $6.0-23.0$ & 35 & 1.42 \\
\hline Prestoea montana (Graham) Nicholson & 56 & 10.4 & 4.7 & $3.0-23.7$ & 280 & 4.10 \\
\hline Rhizophoraceae & & & & & & \\
\hline Cassipourea guianensis Aublet & 12 & 7.8 & 5.3 & $2.0-20.8$ & 60 & 0.47 \\
\hline Rubiaceae & & & & & & \\
\hline Psychotria beteriana DC. & 21 & 4.7 & 1.1 & $3.0-7.0$ & 105 & 0.18 \\
\hline Rudgea hostmanniana Bentham & 3 & 6.8 & 2.6 & $5.0-9.8$ & 15 & 0.05 \\
\hline Rudgea vincentina Urban & 3 & 3.2 & 1.5 & $1.5-4.2$ & 15 & 0.06 \\
\hline Palicourea crocea (Sw.) Roemer \& Schultes & 1 & 3.5 & - & - & 5 & 0.02 \\
\hline Sabiaceae & & & & & & \\
\hline Meliosma herbertii Rolfe & 13 & 8.6 & 3.6 & $3.1-16.6$ & 65 & 0.55 \\
\hline Sapotaceae & & & & & & \\
\hline Chrysophyllum argenteum Jacq. & 26 & 9.2 & 6.8 & $2.6-27.7$ & 130 & 7.00 \\
\hline Pouteria multiflora (A. DC.) Eyma & 3 & 14.5 & 6.3 & 7.3-18.3 & 15 & 0.23 \\
\hline
\end{tabular}


TABLE 1. Continued.

\begin{tabular}{|c|c|c|c|c|c|c|}
\hline \multirow[b]{2}{*}{ Family and species } & \multirow[b]{2}{*}{$\mathrm{N}$} & \multicolumn{3}{|c|}{ Height (m) } & \multirow[b]{2}{*}{ Dens.* } & \multirow[b]{2}{*}{$\mathrm{BA}+$} \\
\hline & & Mean & SD & Range & & \\
\hline \multicolumn{7}{|l|}{ Simaroubaceae } \\
\hline Simarouba amara Aublet & 17 & 17.4 & 4.7 & $9.0-27.0$ & 85 & 3.56 \\
\hline \multicolumn{7}{|l|}{ Symplocaceae } \\
\hline Symplocos martinicensis Jacq. & 1 & 17.4 & - & - & 5 & 0.54 \\
\hline \multicolumn{7}{|l|}{ Verbenaceae } \\
\hline Citharexylum spinosum L. & 19 & 8.1 & 5.0 & $2.5-20.1$ & 95 & 0.46 \\
\hline Unknown A & 2 & 9.1 & 5.8 & $5.0-13.1$ & 10 & 0.09 \\
\hline Unknown B & 3 & 11.7 & 0.5 & $11.3-12.3$ & 15 & 0.09 \\
\hline Unknown C & 1 & 13.0 & - & - & 5 & 0.02 \\
\hline Unknown D & 2 & 16.0 & 1.0 & $15.3-16.6$ & 10 & 0.10 \\
\hline Unknown E & 2 & 16.2 & 12.2 & $7.6-24.9$ & 10 & 0.78 \\
\hline Unknown F & 2 & 11.3 & 0.5 & $10.9-11.6$ & 10 & 0.09 \\
\hline
\end{tabular}

${ }^{*}$ Density $=$ Number of trees per species per hectare.

tBA $=$ Total basal area $\left(\mathrm{m}^{2}\right)$ per species per hectare.

TABLE 2. Structural summary of the three forest types in the Grand Etang Forest.

\begin{tabular}{lccr}
\hline \hline & Primary & Secondary & Palm brake \\
\hline Percentage of occurrence & 55 & 30 & 15 \\
Tree density per hectare & & & \\
Mean & $2,509.1$ & $4,283.3$ & $1,700.0$ \\
SD & 816.6 & 515.4 & 200.0 \\
Range & $900-3,400$ & $3,600-4,800$ & $1,500-1,900$ \\
Total basal area per hectare $\left(\mathrm{m}^{2}\right)$ & & & \\
Mean & 110.3 & 80.4 & 26.8 \\
SD & 70.9 & 33.3 & 9.8 \\
Range & $5.2-238.3$ & $44.3-132.9$ & $17.3-36.8$ \\
Number of species per are $(50 \mathrm{~m} \times 2 \mathrm{~m})$ & & & 6.3 \\
Mean & 9.0 & 14.7 & 0.6 \\
SD & 2.2 & 2.5 & $6-7$ \\
Range & $6-13$ & $10-17$ & 10.4 \\
Tree height $(\mathrm{m})$ & & & 5.5 \\
Mean & 13.1 & 5.1 & $3.0-26.8$ \\
SD & 8.5 & $0.3-28.7$ & \\
Range & $1.5-51.9$ & & \\
\hline
\end{tabular}

marked species difference between the Grand Etang and Puerto Rican forests occurred with Licania ternatensis - a subdominant tree in Lesser Antillean forests (Beard 1949). It was the most common tree species in terms of stems per hectare and third most common species in terms of basal area in the Grand Etang forest, but it is absent from Puerto Rico (Brandeis et al. 2007). In addition, and consistent with Beard's (1949) previous characterization of Grenadian forests in the 1940s, the overall species composition of less dominant species in the Grand Etang forest differed from those in
Puerto Rican wet/rain forest and lower montane wet/rain forest (Brandeis et al. 2007). Finally, the Grand Etang forest of the 1990s generally appeared to be of similar stature to Puerto Rican wet/rain forest and lower montane wet/rain forest stands measured previous to Hurricane Hugo (Frangi and Lugo, 1991).

The overall mosaic of stands of varying sizes and species composition indicated by our primary forest, secondary forest and palm brake plots in the Grand Etang generally fits the pattern expected by Weaver (1998) in a hurricane influenced and moun- 
tainous Caribbean wet/rain forest. He concluded that the varying ecological conditions found on mountainous tropical island ridge tops, slopes and valley bottoms combined with the varying wind speeds and trajectories of hurricanes across the islands produce the resulting complex forest structure and composition. The hurricane of 1955 must have impacted certain areas of the Grand Etang forest more heavily than others. Those areas that suffered the most significant damage became the secondary forest areas represented in our plots while those areas with significant post hurricane large tree survivorship remained primary forest.

The 2004 hurricane that crossed the Grand Etang forest after our study was completed has begun yet another major disturbance and recovery cycle. While Grenada's Grand Etang forest shares many characteristics with those found in the well studied wet/rain forest and lower montane wet/rain forest of Puerto Rico, it is different. The hurricane disturbance/recovery process over the short and long term is now well understood in the Greater Antillean forests of Puerto Rico (e.g., Dallmeier et al. 1998, Frangi and Lugo 1991, Scatena et al. 1993, Scatena et al. 1996, Weaver 1989, Weaver 1998). Future studies conducted in the Grand Etang forest, when combined with our study, would provide the same short and long term perspective for a Lesser Antillean forest and be a fascinating comparison to the Puerto Rican forests.

Acknowledgments.-This manuscript is dedicated in memoriam to the botanist Dr. Ernest Wilson. Dr. Ernest Wilson, Mr. Dean Jules, Mr. Roland Roberts, Mr. Alban Clark, and Mr. Desmond Dumont spent many tireless hours at our field site over the years keying out plants and helping to conduct forest surveys. We thank the Honorable Mr. Tillman Thomas and Ms. Lana McPhail of the Ministries of Tourism and Labour of the Government of Grenada, Mr. Michael Philip and Mr. Raymond Walker of the Grenada National Parks and Protected Areas, and Mr. Allan Joseph of the Grenada Forestry Department for the permission they generously granted to us to conduct research in the Grand Etang National Park and Forest Reserve. We are indebted to Mr. Michael Jessamy for his continued help on many fronts. We are grateful to Ms. Heather Bruce, Mr. Oscar "Chest" Andall and the many students who helped us in the field. We thank the anonymous reviewers for their helpful criticism during the preparation of this manuscript. This research was supported by the Windward Islands Research and Education Foundation, The Rockefeller University, and the Yerkes Regional Primate Research Center.

\section{LITERATURE CITED}

Beard, J. S. 1944. Climax vegetation in tropical America. Ecology 25(2): 127-158.

Beard, J. S. 1949. The Natural Vegetation of the Windward and Leeward Islands. Oxford: Oxford University Press.

Brandeis, T. J., Helmer, E. H., and Oswalt, S. N. 2007. The Status of Puerto Rico's Forests, 2003. Resource Bulletin SRS-119. USDA Forest Service Southern Research Station, Ashville, NC.

Caribbean Conservation Association. 1991. Grenada Environmental Profile. Barbados: Caribbean Conservation Association.

Dallmeier, F., Comiskey, J. A., and Scatena, F. N. 1998. Five years of forest dynamics following hurricane Hugo in Puerto Rico's Luquillo Experimental Forest. In Forest Biodiversity in North, Central and South America and the Caribbean. Research and Monitoring, eds. F. Dallmeier and J. A. Comiskey, 231-248, Washington D.C.: Parthenon Publishing Group.

Frangi, J. L. and Lugo, A. E. 1991. Hurricane damage to a flood plain forest in the Luquillo Mountains of Puerto Rico. Biotropica 23:324-335.

Grenada Government and Organization of American States. 1988. Plan and Policy for a System of National Parks and Protected Areas, Washington, DC: Dept. Reg. Dev., OAS.

Glenn, M. E. 1996. The Natural History and Ecology of the Mona Monkey (Cercopithecus mona Schreber 1774) on the Island of Grenada, West Indies. Doctoral Dissertation. Evanston, Illinois: Northwestern University.

Glenn, M. E. 1997. Group size and group composition of the mona monkey (Cercopithecus mona) on the island of Grenada, West Indies. American Journal of Primatology 43(2): 167-173.

Glenn, M. E. 1998. Population density of Cercopithecus mona on the Caribbean island of Grenada. Folia Primatologica 69: 167-171.

Horsburgh, A., Matisoo-Smith, E., Glenn, M. E., and Bensen, K. J. 2002. A genetic study of a translocated guenon. In The Guenons: Diversity and Adaptation in African Monkeys, eds. M. E. Glenn and M. Cords, 
99-109, New York: Kluwer Academic/Plenum Publishers.

Howard, R. A. 1989. Flora of the Lesser Antilles, Leeward and Windward Islands.

Arnold Arboretum. Jamaica Plains, Massachusetts: Harvard University Press.

Scatena, F. N., Moya, S., Estrada, C., and Chinea, J. D. 1996. The first five years in the reorganization of above ground biomass and nutrient use following hurricane Hugo in the Bisley Experimental Watersheds, Luquillo Experimental Forest, Puerto Rico. Biotropica 28:424-440.

Scatena, F. N., Silver, W. L., Siccama, A., Johnson, A., and Sanchez, M. J. 1993. Biomass and nutrient content of the Bisley Experimental Watershed, Luquillo Experimental Forest, Puerto Rico, before and after Hurricane Hugo, 1989. Biotropica 25:15-27.

Weaver, P. L. 1989. Forest changes after hurricanes in Puerto Rico's Luquillo mountains. Interciencia 14: 181-192.

Weaver. P. L. 1998. Hurricane effects and long-term recovery in a subtropical rain forest. In Forest Biodiversity in North, Central and South America and the Caribbean. Research and Monitoring, eds. F. Dallmeier and J. A. Comiskey, 249-270, Washington D.C.: Parthenon Publishing Group. 